\title{
Robot Mobile Otonom Menggunakan Metode Odometry
}

\author{
Edi Rakhman ${ }^{1}$, Noor Cholis Basjaruddin ${ }^{2}$, Vito Eka Pramudhita Susanto ${ }^{3}$ \\ Program Studi Teknik Elektro, \\ Jurusan Teknik Elektro, \\ Politeknik Negeri Bandung \\ 1iedr@polban.ac.id, 2noorcholis@polban.ac.id, vito.pramudhita@gmail.com
}

\begin{abstract}
Ringkasan
Robot mobile otonom (autonomous mobile robot, AMR) banyak digunakan baik di industri maupun lingkungan rumah tangga. Robot jenis ini mempunyai kemampuan bergerak menuju tempat tertentu secara otomatis. Penggunaan GPS pada tempat tertutup dan area terbatas belum dapat memenuhi kebutuhan karena keterbatasan resolusi GPS. Pada penelitian ini dikembangkan robot mobile yang mampu menuju titik tertentu dengan memanfaatkan sensor rotary encoder dan metode odometry. Koordinat tujuan diberikan ke robot dan kemudian secara otomatis robot bergerak ke arah titik koordinat tujuan. Pengujian dilakukan dengan memberikan tujuan dengan jarak berbeda yaitu $60 \mathrm{~cm}, 100 \mathrm{~cm}$, $150 \mathrm{~cm}, 200 \mathrm{~cm}$, dan $250 \mathrm{~cm}$. Rata-rata galat perhitungan odometry yang dihitung pada jarak tersebut adalah sebesar $0.5 \mathrm{~cm}, 2.63 \mathrm{~cm}, 1.65 \mathrm{~cm}$, dan $1.1 \mathrm{~cm}$. Pada pengukuran secara riil didapatkan galat sebesar $7 \mathrm{~cm}, 13 \mathrm{~cm}, 10 \mathrm{~cm}$, dan $20 \mathrm{~cm}$. Pengujian rute langsung mempunyai nilai galat yang paling kecil dibanding pengujian rute 1 dan rute 2 yaitu $0,11 \mathrm{~cm}$ untuk tujuan $x$ dan $0,25 \mathrm{~cm}$ untuk tujuan $y$. Pada pengukuran posisi riil mempunyai galat $x=3 \mathrm{~cm}$ dan $y=2 \mathrm{~cm}$.
\end{abstract}

Kata kunci: robot mobile otonom; odometry; rotary encoder, GPS

\section{Pendahuluan}

Autonomous mobile robot (robot mobile otonom) adalah robot yang mampu bergerak ke tempat tujuan secara otomatis. Robot ini banyak digunakan di lingkungan industri maupun rumah tangga. Beberapa aplikasi di industri dari jenis robot ini antara lain patroli keamanan di area industri, inspeksi rutin pada industri kimia, gas, dan minyak, serta pengantar barang. Adapun aplikasi di lingkungan rumah tangga antara lain untuk melayani manula, membersihkan rumah, dan patroli keamanaan rumah. Beberapa industri yang saat ini telah memproduksi AMR antara lain SMP Robotic, Aethon, dan Swisslog [1].

Aplikasi AMR yang terus meluas dan potensi pasar yang besar mendorong penelitian di bidang AMR terus dilakukan. Beberapa penelitian di bidang AMR antara lain telah dilaksanakan oleh [2], [3], dan [4]. Pada penelitian [2] dikembangkan AMR untuk lokalisasi akses poin dengan menggunakan metode kolaboratif sedangkan pada penelitian [3], dan [4] dikembangkan AMR dengan algoritma verbalisasi dan metode Qualitative-Probabilistic.

AMR lebih banyak digunakan pada area terbatas seperti pabrik, kawasan industri, rumah sakit, dan rumah. Aplikasi pada area terbatas dan umumnya tertutup 
membutuhkan sistem navigasi AMR yang tidak berbasis GPS. Saat ini resolusi GPS belum mendukung untuk aplikas pada sistem navigasi AMR yang beroperasi pada area terbatas dan tertutup.

Penggunaan metode odometry pada sistem navigasi AMR adalah salah satu jawaban pada persoalan keterbatasan resolusi GPS. Penelitian AMR dengan metode odometry antara lain telah dilaksanakan oleh [5], [6], dan [7]. Pada penelitan AMR yang pertama dikembangkan metode odometry digabung dengan sensor kamera, penelitian kedua odometry dan sensor ultrasonic LPS (Local Positioning System) serta penelitian ketiga menggabungkan odometry dan Wireless Sensor Network (WSN). Teknologi lain yang saat ini juga dikembangkan untuk sistem navigasi AMR pada area terbatas antara lain kamera [8] dan [9], sonar [10], dan radar [11]. Penelitian ini dapat dijadikan dasar untuk pengembangan kendali berbasis rute menggunakan GPS yang memungkinkan kendaraan mampu mengikuti rute yang areanya lebih luas [12]. Penelitian ini juga dapat menjadi dasar dalam pengembangan kendaraan otonom yang saat ini sudah mulai digunakan [13] dan [14].

Pembahasan pada artikel ilmiah ini dimulai dari pendahuluan. Pada bagian latar belakang penelitian disampaikan state of the art dan kontribusi dari penelitian ini. Pada bagian metode penelitian dibahas blok diagram dan cara kerja sistem yang dikembangkan, metode odometry, dan purwarupa AMR. Data hasil pengujian dianalisis pada bagian hasil dan pembahasan. Artikel ilmiah ini diakhiri dengan kesimpulan yang merupakan pernyataan atas hasil penelitian yang telah dilakukan.

\section{Metode}

Prinsip kerja pengendalian menggunakan metode odometry adalah mengolah keluaran sensor rotary encoder dengan persamaan matematis dan menghasilkan koordinat kartesian tujuan. Proses tersebut berulang sampai robot mencapai titik tujuan.

\subsection{Metode Odometry}

Metode Odometry adalah metode perhitungan posisi dengan menggunakan data dari pergerakan aktuator. Perhitungan posisi tersebut dilakukan terus menerus sampai mencapai posisi tujuan. Secara umum odometry digunakan untuk memperkirakan posisi relatif terhadap posisi awal.

Jika odometry digunakan pada robot maka posisi relatif robot dapat ditentukan dengan menggunakan perhitungan jumlah pulsa yang dihasilkan oleh sensor rotary encoder. Jumlah pulsa tersebut kemudian dikonversi ke besaran jarak dalam satuan milimeter. Perhatikan Persamaan (1) dan (2).

$$
\begin{gathered}
\text { keliling_roda }=2 \pi r \\
\text { pulsa_per_mm }=\text { resolusi_encoder } / \text { keliling_roda }
\end{gathered}
$$

Jika robot menggunakan sistem penggerak diferensial dan dimisalkan jumlah pulsa_per_mm untuk roda kanan adalah pulsa_enc_kanan dan roda kiri adalah pulsa_enc_kiri dan jarak antara dua roda adalah as_roda maka didapatkan jarak tempuh dan sudut orientasi $\theta$ seperti pada Persamaan (3) dan (4).

$$
\begin{gathered}
\text { jarak_tempuh }=(\text { pulsa_enc_kanan }+ \text { pulsa_enc_kiri }) / 2 \\
\theta=(\text { pulsa_enc_kiri }- \text { pulsa_enc_kanan }) / \text { as_roda }
\end{gathered}
$$


Satuan $\theta$ adalah radian maka untuk mengetahui sudut dalam derajat digunakan rumus sebagai berikut :

$$
\theta \_ \text {derajat }=\theta \times 100 / \pi
$$

Nilai $\theta$ _derajat akan negatif (-) saat robot berputar berlawanan arah jarum jam dan akan bernilai positif $(+)$ saat robot berputar searah dengan jarum jam. Jika jarak dan sudut (jarak_tempuh dan $\theta$ ) diketahui maka dapat diketahui koordinat $X$ dan koordinat $\mathrm{Y}$ dengan persamaan trigonometri.

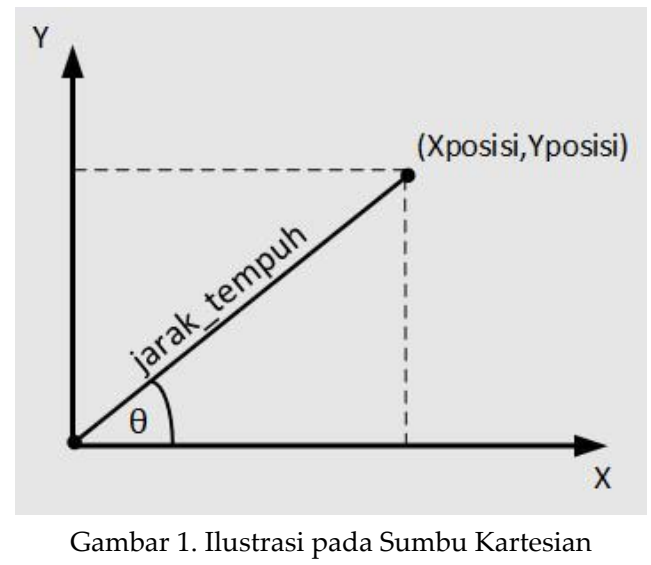

Berdasarkan Gambar 1 maka koordinat robot dapat dihitung dengan rumus Persamaan (6) dan (7).

$$
\begin{aligned}
& \text { Xposisi }=(\text { jarak_tempuh })(\sin (\theta)) \\
& \text { Yposisi }=(\text { jarak_tempuh })(\cos (\theta))
\end{aligned}
$$

Selisih titik tujuan dan posisi saat ini menghasilkan $\mathrm{x}$ dan y yang merupakan arah robot sedangkan jarak antara posisi saat ini dan titik tujuan dapat ditentukan dengan menggunakan teorema phytagoras. Lihat Persamaan (8), (9), dan (10).

$$
\begin{gathered}
x=\text { Xtujuan }- \text { Xposisi } \\
y=\text { Ytujuan }- \text { Yposisi } \\
\text { jarak_target }=\sqrt{ }\left(x^{\wedge} 2+y^{\wedge} 2\right)
\end{gathered}
$$

Berdasarkan Persamaan (8) dan (9) robot akan mengarahkan pergerakkannya sedangkan berdasarkan Persamaan (10) robot akan tahu seberapa jauh harus bergerak.

\subsection{Diagram Blok dan Cara Kerja}

Diagram blok robot mobile yang dikembangkan dapat dilihat pada Gambar 2. Cara kerja dari sistem ini adalah robot akan menerima masukan berupa referensi rute berupa kumpulan titik koordinat $\mathrm{x}$ dan $\mathrm{y}$ yang akan dituju dari ponsel Android melalui Bluetooth HC - 05. Motor kemudian menggerakkan robot ke arah titik koordinat pertama, kedua, dan selanjutnya sesuai dengan referensi yang diberikan. Pada saat yang sama jumlah pulsa dihitung dari putaran roda menggunakan sensor rotary encoder dan kemudian diolah dengan program odometry pada sistem mikrokontroler untuk mengetahui posisi robot saat ini. Apabila sudah mencapai titik akhir robot akan berhenti. 


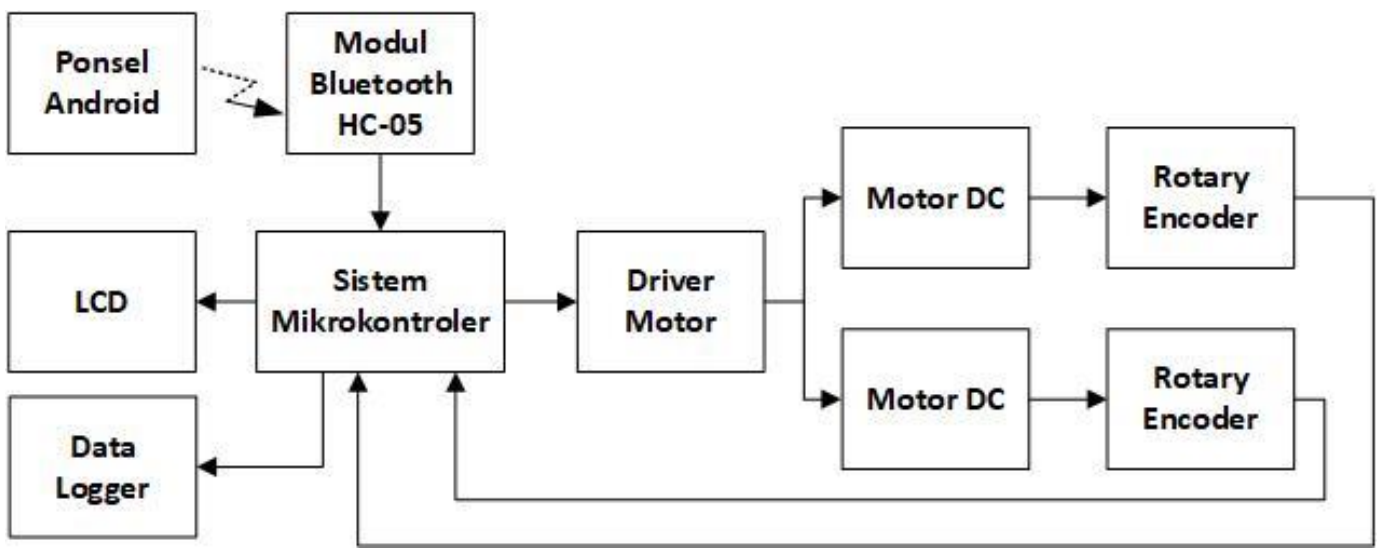

Gambar 2. Diagram blok sistem

\subsection{Perancangan Perangkat Keras}

Modul elektronik yang digunakan pada robot diletakkan pada robot mobile kit berukuran $25 \mathrm{~cm} \times 15 \mathrm{~cm}$. Sistem mikrokontroler Arduino sebagai pusat pemroses diletakkan di tengah karena akan banyak pengkabelan ke komponen elektronika lainnya. Driver L298N diletakan di belakang supaya dekat dengan kedua motor yang disimpan di belakang sehingga kabelnya tidak terlalu panjang. Baterai LiPo disimpan di chassis bawah. Rancangan peletakan modul pada robot dapat dilihat di Gambar 3.

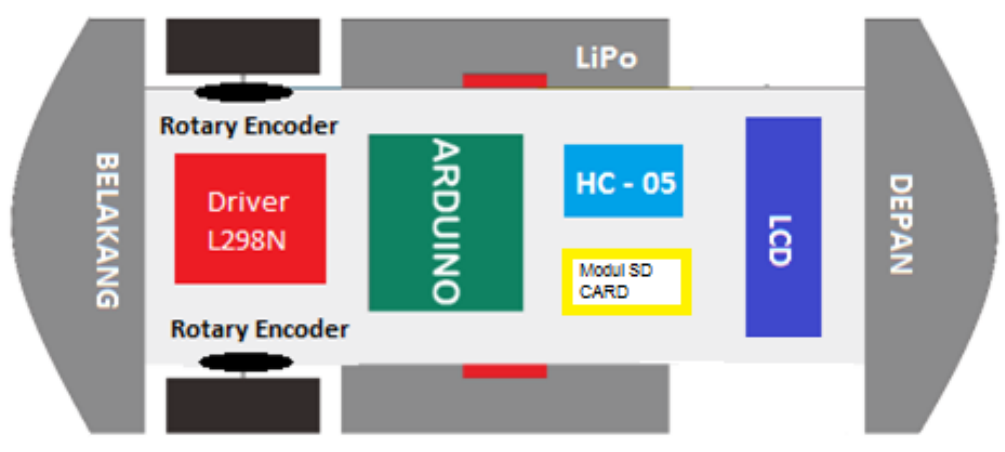

Gambar 2. Peletakan Modul pada Robot

\subsection{Perancangan Perangkat Lunak}

Pada perancangan perangkat lunak dibuat diagram alir pemograman agar alat dapat berfungsi sesuai dengan perancangan dan tujuan yang diinginkan. Robot mempunyai tugas untuk mencapai target yang diinginkan. Target berupa koordinat kartesian $(x, y)$ dengan sumbu $x$ positif mewakili arah maju robot dan sumbu $y$ positif mewakili arah kiri robot. Pada Gambar 4 menunjukkan diagram alir odometry. 


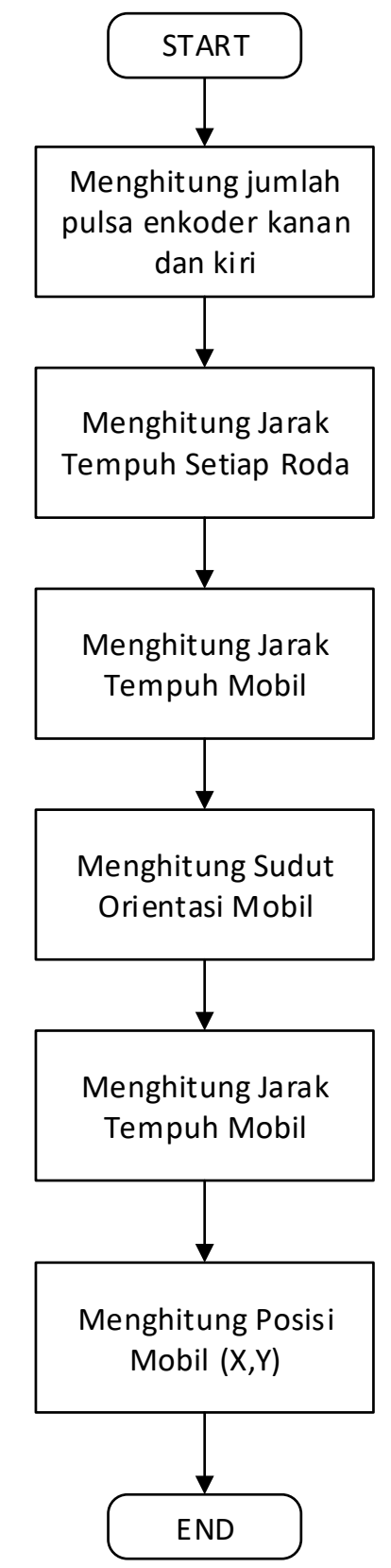

Gambar 3. Diagram alir odemetry

Dari Gambar 4, menghitung jumlah pulsa yang diperoleh dari enkoder kanan dan kiri menggunakan Persamaan (1) dan (2) dengan variabelnya adalah pulsa_enc_kanan dan pulsa_enc_kiri. Kedua variabel tersebut digunakan untuk menghitung jarak_tempuh seperti pada Persamaan (3). Selanjutnya variabel jarak_tempuh digunakan untuk menghitung Sudut Orientasi Mobil $\theta_{-}$derajat seperti pada Persamaan (5) yang terlebih dahulu dihitung sudut $\theta$ seperti pada Persamaan (4). Sudut orientasi ini kemudian digunakan untuk menghitung jarak tempuh mobil seperti pada Persamaan (10) dengan variabel jarak_target. Dengan melihat Gambar 1. bahwa Persamaan (10) dihitung menggunakan persamaan (6) s.d. (9). Sedangkan, Posisi Mobil terjadi di titik (Xposisi, Yposisi) seperti pada persamaan (6) dan (7). Penentuan posisi mobil pada metode ini 
bersifat kendali lingkar terbuka karena tidak dilengkapi dengan umpan balik bahwa posisi sudah berada pada koordinat tujuan.

\section{Hasil dan Pembahasan}

\subsection{Realisasi Robot Mobile}

Hasil realisasi robot mobile yang dikembangkan dapat dilihat pada Gambar 5.

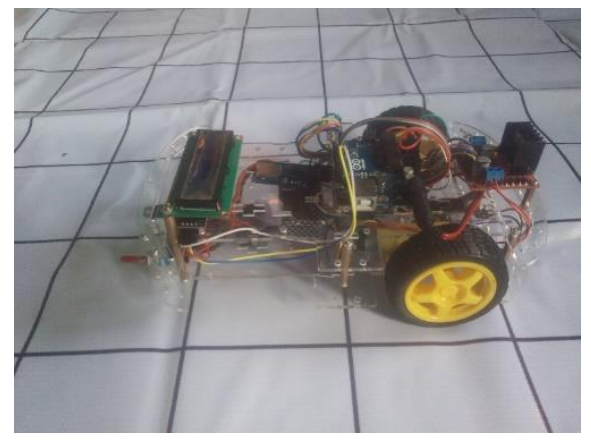

Gambar 5. Realisasi Robot Mobile

Pengujian dilakukan dengan memberikan koordinat tujuan pada robot. Pengujian pertama adalah pengujian jarak tempuh sedangkan pengujian kedua adalah pengujian rute tempuh. Pada pengujian rute tempuh robot akan melalui tiga rute yaitu rute langsung, rute 1 , dan rute 2 .

\subsection{Pengujian Jarak}

Pada pengujian jarak, robot diberi tujuan $60 \mathrm{~cm}, 100 \mathrm{~cm}, 150 \mathrm{~cm}, 200 \mathrm{~cm}$, dan $250 \mathrm{~cm}$. Tujuan tersebut merupakan arah maju dari robot untuk bergerak secara lurus. Pada Gambar 6 disajikan hasil pengujian jarak $60 \mathrm{~cm}$.

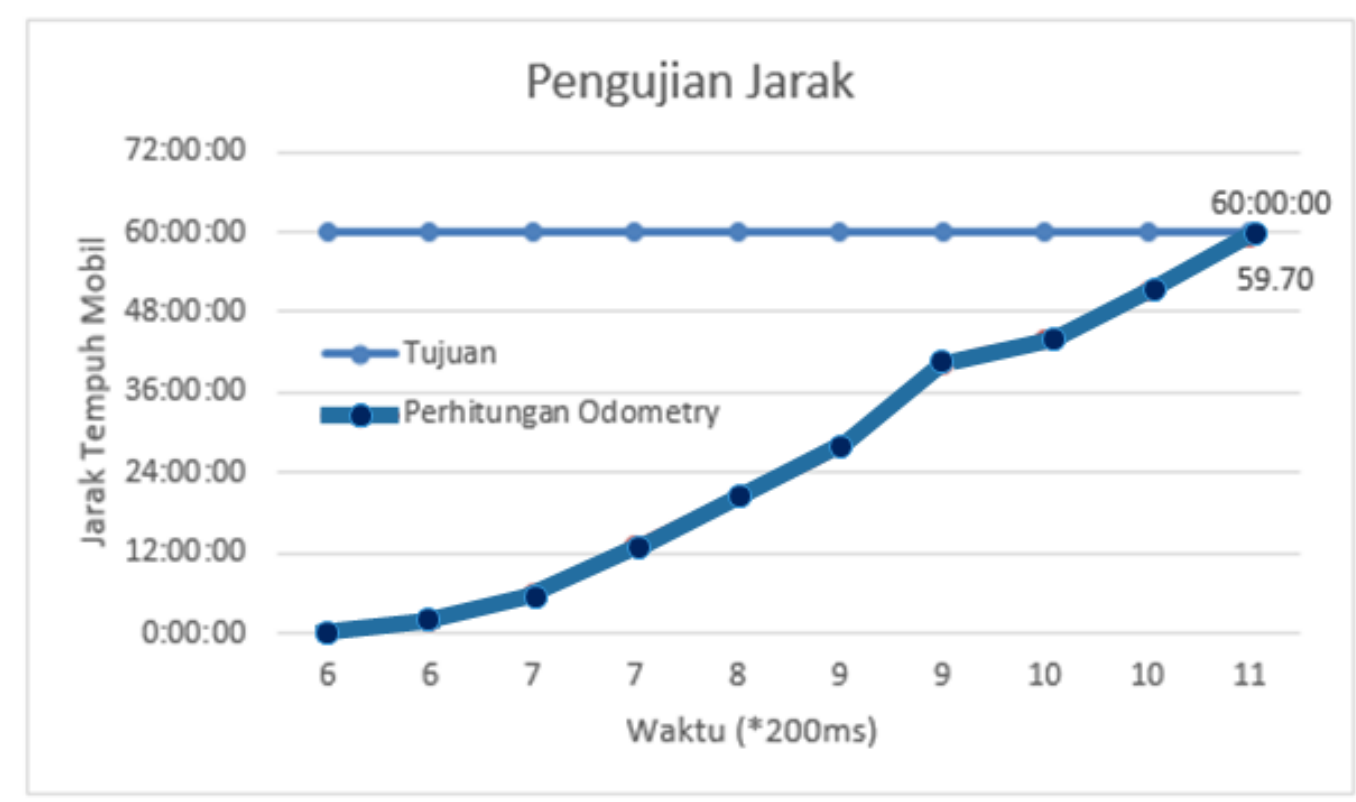

Gambar 6. Grafik Hasil Pengujian Jarak $60 \mathrm{~cm}$ 
Pada Gambar 6 dapat dilihat saat awal robot berada pada $0 \mathrm{~cm}$ dan tujuan yang diberikan adalah $60 \mathrm{~cm}$. Kemudian robot melaju menuju jarak $60 \mathrm{~cm}$, pada saat melaju proses perhitungan odometry dilakukan untuk mengetahui posisi robot saat ini. Robot berhenti ketika sudah mencapai tujuan. Pada perhitungan odometry didapatkan hasil $59,7 \mathrm{~cm}$ sehingga masih terdapat galat sebesar $0,3 \mathrm{~cm}$. Galat yang terjadi disebabkan perbedaan pembacaan jumlah sinyal encoder antara roda kanan dan kiri karena getaran pada robot saat bergerak. Getaran atau permukaan lintasan yang tidak rata menyebabkan kegagalan dalam pembacaan jumlah pulsa oleh sensor karena pada proses pendeteksian lubang pada poros encoder terganggu. Selain itu jika permukaan lintasan tidak rata roda robot dapat tertahan tetapi perhitungan jumlah pulsa tetap terjadi hal ini juga dapat menyebabkan perbedaan pembacaan jumlah sinyal.

\subsection{Pengujian Rute Langsung}

Tujuan yang diberikan adalah koordinat $(80,60) \mathrm{cm}$. Robot pertama-tama berada pada koordinat $(0,0)$. Gambar 7 menunjukkan robot berada pada posisi $(0,0) \mathrm{cm}$.

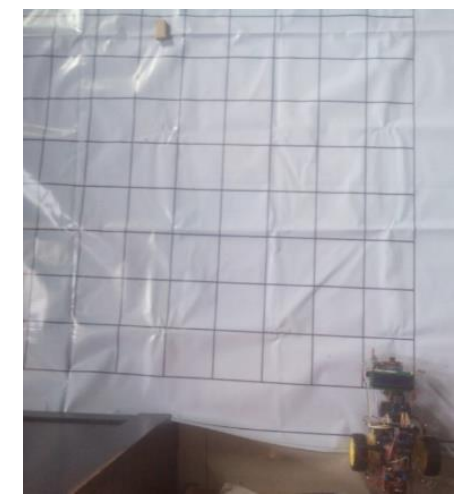

Gambar 7. Posisi Robot pada $(0,0) \mathrm{cm}$

Ketika dijalankan robot berjalan menuju koordinat $(80,60) \mathrm{cm}$ seperti dapat dilihat pada Gambar 8. Grafik perjalanan robot dapat dilihat pada Gambar 9.

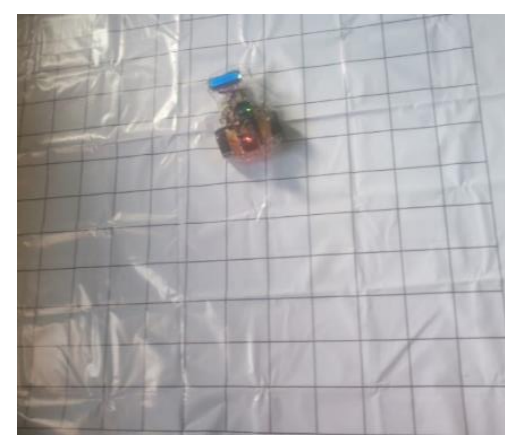

Gambar 8. Posisi Robot pada $(80,60) \mathrm{cm}$ 


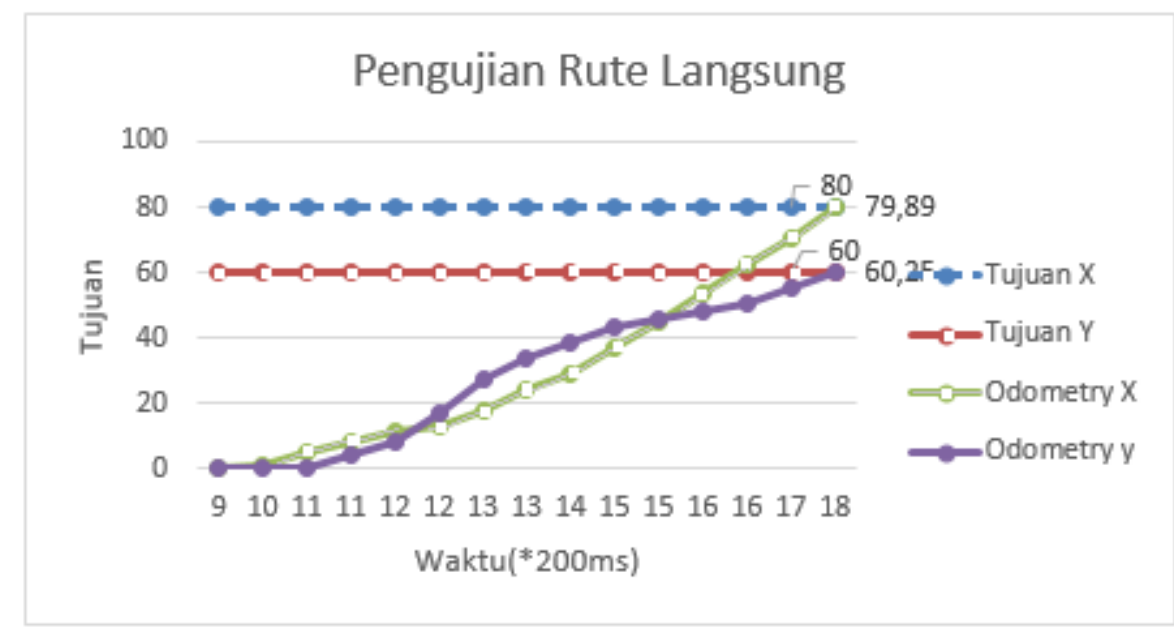

Gambar 9. Grafik Pengujian Rute Langsung ke $(80,60)$

Pada pengujian rute langsung terdapat galat $0,11 \mathrm{~cm}$ dan $0,25 \mathrm{~cm}$. Galat tersebut sangat kecil dan membuktikan perhitungan odometry dapat terlaksana dengan baik.

\subsubsection{Pengujian Rute 1}

Pada pengujian rute 1 robot mula-mula berada di koordinat $(0,0) \mathrm{cm}$ kemudian menuju koordinat $(80,60) \mathrm{cm}$. Pada rute 1 robot terlebih dahulu menuju koordinat $(80,0)$ $\mathrm{cm}$. Setelah sampai pada tujuan pertama, robot menuju tujuan selanjutnya yaitu $(80,60)$ $\mathrm{cm}$. Ilustrasi rute 1 dapat dilihat pada Gambar 10. Hasil pengujian rute 1 ditampilkan pada Gambar 11 dan Gambar 12.

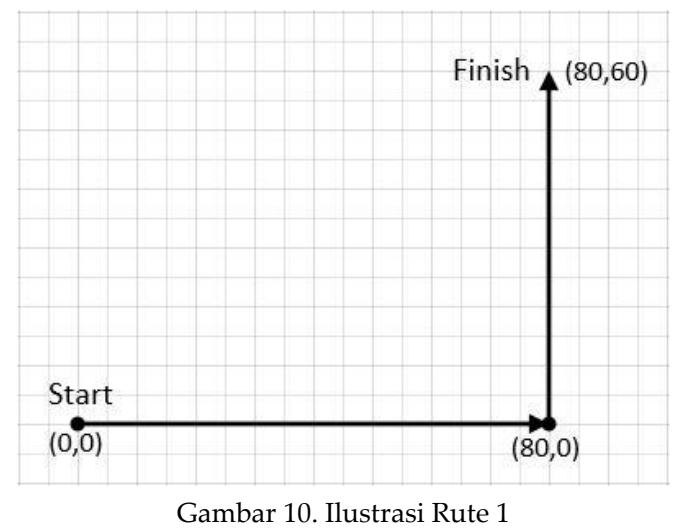

Pada Gambar 11 dapat dilihat terdapat galat yang sangat kecil yaitu sekitar 0,77 cm sedangkan pada Gambar 12 terdapat galat yang cukup besar yaitu sekitar $17 \mathrm{~cm}$ pada tujuan X (lihat detik ke $800 \mathrm{~ms}$ ) dikarenakan robot berbelok ke arah tujuan Y sehingga roda kanan berputar untuk membelokkan robot. Putaran tersebut menyebabkan jumlah sinyal yang terbaca oleh sensor menjadi lebih besar sehingga menghasilkan perhitungan yang mempunyai galat yang besar. Ketika robot sudah menghadap ke tujuan $Y$ dan menuju tujuan $Y$, perlahan-lahan perhitungan odometry $X$ kembali mendekati ke tujuan $X$. Sedangkan perhitungan odometry $Y$ ketika mencapai tujuan $Y$ memiliki galat 2,52 cm. 


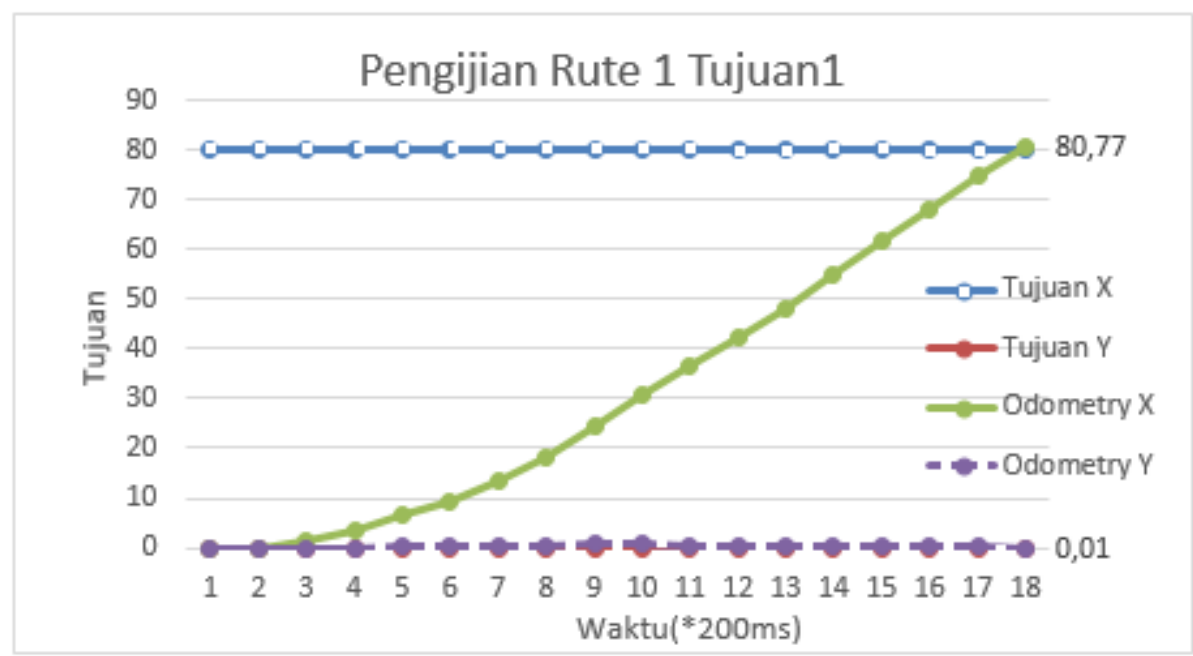

Gambar 11. Grafik Pengujian Rute 1 Tujuan 1

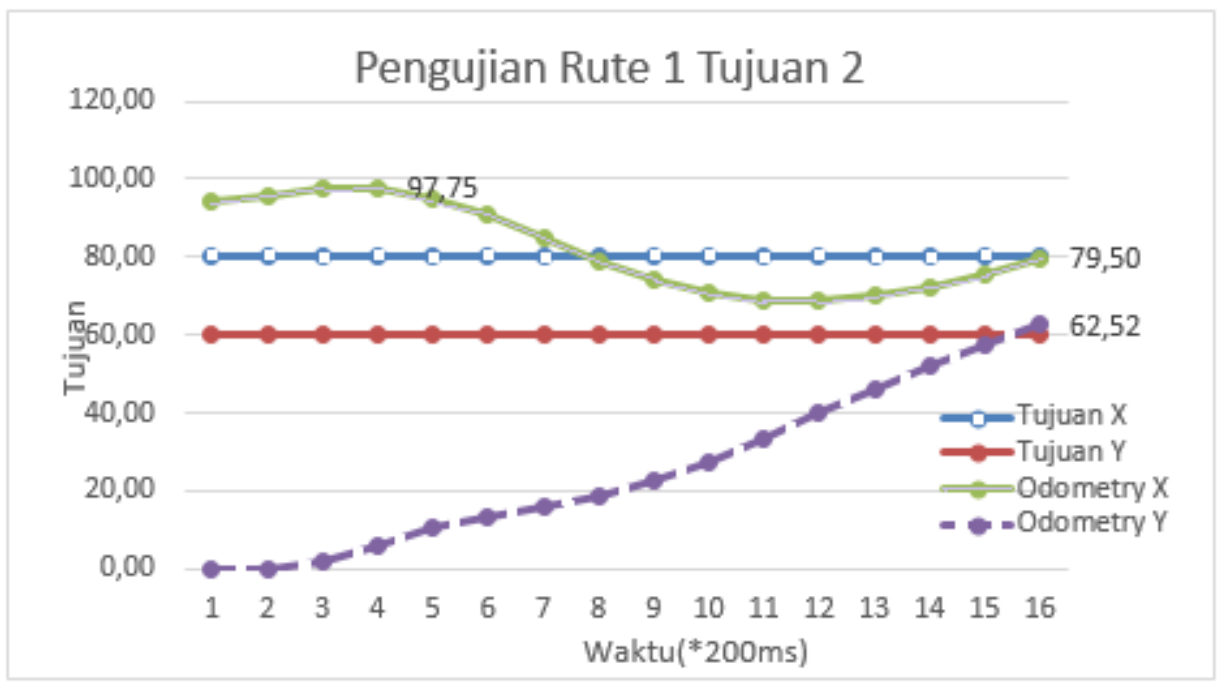

Gambar 12. Grafik Pengujian Rute 1 Tujuan 2

\subsubsection{Pengujian Rute 2}

Pada pengujian rute 2 robot mula-mula berada di koordinat $(0,0) \mathrm{cm}$ kemudian menuju koordinat $(80,60) \mathrm{cm}$. Pada rute 2 robot terlebih dahulu menuju koordinat $(60,0)$ $\mathrm{cm}$. Setelah sampai pada tujuan pertama, robot menuju tujuan selanjutnya yaitu $(80,60)$ $\mathrm{cm}$. Lihat ilustrasi rute 2 pada Gambar 13. Hasil pengujian rute 2 ditampilkan pada Gambar 14 dan Gambar 15.

Pada Gambar 14 diperlihatkan hasil pengujian rute 2, dapat dilihat terdapat galat yang sangat kecil yaitu sekitar 0,21 cm sedangkan pada Gambar 15 terdapat galat yang cukup besar yaitu sekitar 7,86 cm pada tujuan Y (lihat pada detik ke 1,6 s - 1,8 s) dikarenakan robot berbelok ke arah tujuan $\mathrm{X}$ sehingga roda kiri berputar untuk membelokkan robot. Putaran tersebut menyebabakan jumlah sinyal yang terbaca oleh sensor menjadi lebih besar sehingga menghasilkan hasil perhitungan yang mempunyai galat yang besar. Ketika robot sudah menghadap ke tujuan $X$ dan menuju tujuan $X$, perlahan-lahan perhitungan odometry Y kembali mendekati ke tujuan Y. Sedangkan perhitungan odometry $X$ ketika mencapai tujuan $X$ memiliki galat $2,73 \mathrm{~cm}$. 


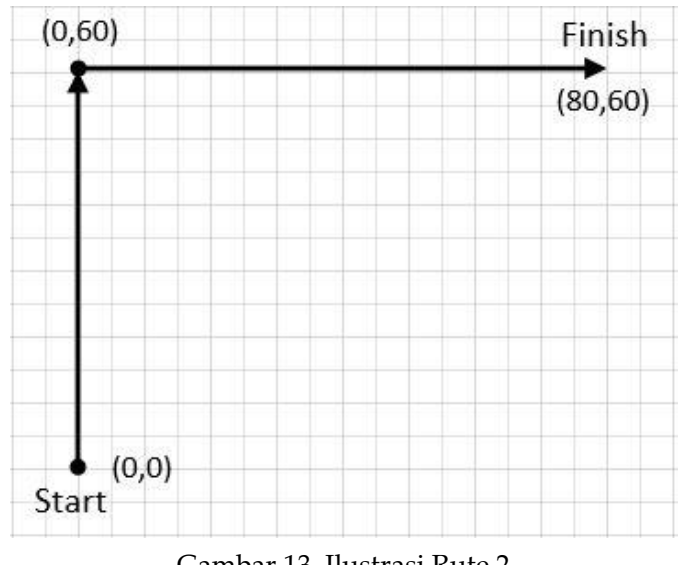

Gambar 13. Ilustrasi Rute 2

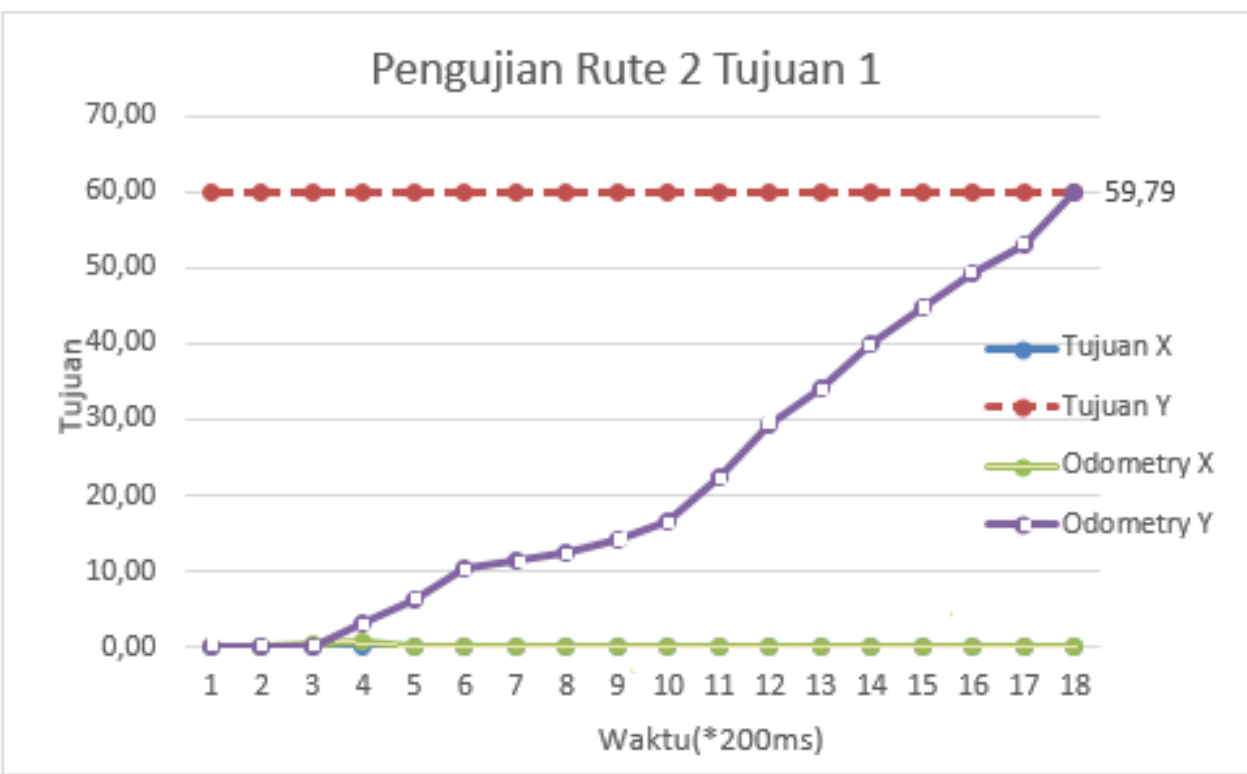

Gambar 14. Grafik Pengujian Rute 2 Tujuan 1

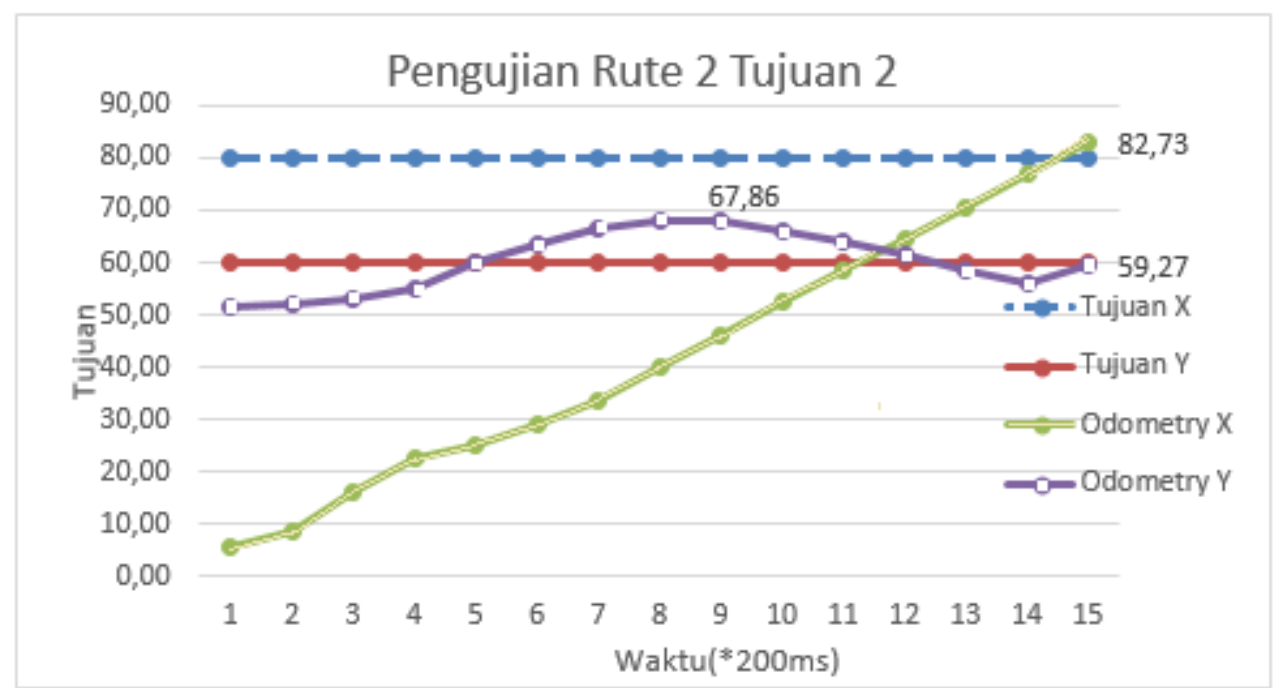

Gambar 15. Grafik Pengujian Rute 2 Tujuan 2 


\section{Kesimpulan}

Sistem navigasi robot mobile otonom dapat dibangun dengan menggunakan metode odometry. Secara umum AMR yang dikembangkan dapat mencapai titik tujuan dengan rute yang telah ditetapkan. Pada pengujian jarak $60 \mathrm{~cm}, 100 \mathrm{~cm}, 150 \mathrm{~cm}, 200 \mathrm{~cm}$, dan 250 $\mathrm{cm}$ rata-rata galat perhitungan odometry adalah $0,5 \mathrm{~cm}, 2,63 \mathrm{~cm}, 1,65 \mathrm{~cm}$, dan $1.1 \mathrm{~cm}$. Galat tersebut termasuk kecil sehingga penggunaan metode odometry pada sistem navigasi AMR dapat diandalkan.

Pada pengujian rute langsung, rute 1, dan rute 2, robot mampu menuju ke arah tujuan yang diberikan. Pengujian rute langsung mempunyai nilai galat yang paling kecil yaitu $0,11 \mathrm{~cm}$ untuk tujuan $X$ dan $0,25 \mathrm{~cm}$ untuk tujuan $Y$. Getaran pada robot dan permukaan lintasan yang tidak rata mempengaruhi pembacaan jumlah pulsa pada sensor sehingga mempengaruhi juga hasil dari perhitungan odometry pada robot.

\section{Daftar Pustaka}

[1] B. Reeder, "Top 10 Companies that Focus on the Next Generation of Autonomous Mobile Robotics," RG-Group, 2018.

[2] F. Awad, M. Naserllah, A. Omar, A. A.-H. dan A. Al-Taj, "Collaborative Indoor Access Point Localization Using Autonomous Mobile Robot Swarm," Sensors 2018, vol. 18, no. 2, p. 407, 2018.

[3] S. Rosenthal, S. P. Selvaraj dan M. Veloso, "Verbalization: Narration of Autonomous Robot Experience," dalam The Twenty-Fifth International Joint Conference on Artificial Intelligence (IJCAI-16), New York, 2016.

[4] V. F. Pereira, F. G. Cozman, P. E. Santos dan M. F. Martins, "A QualitativeProbabilistic Approach to Autonomous Mobile Robot Self Localisation and Self Vision Calibration," dalam Brazilian Conference on Intelligent Systems (BRACIS), Fortaleza, 2013.

[5] D. Pizarro, M. Mazo, E. Santiso, M. Marron, D. Jimenez, S. Cobreces dan C. Losada, "Localization of Mobile Robots Using Odometry and an External," Sensors 2010, vol. 10, pp. 3655 - 3680, 2010.

[6] B.-S. Cho, W.-J. Seo, W.-s. Moon dan K.-R. Baek, "Positioning of a mobile robot based on odometry and a new ultrasonic LPS," International Journal of Control, Automation and Systems, vol. 11, no. 2, p. 333-345, 2013.

[7] G. Fu, J. Zhang, W. Chen, F. Peng, P. Yang dan C. Chen, "Precise Localization of Mobile Robots via Odometry and Wireless Sensor Network," International Journal of Advanced Robotic Systems, vol. 10, p. 203:2013, 2013.

[8] A. R. d. Geus, M. H. Stoppa dan S. F. d. Silva, "PathFinder: An autonomous mobile robot guided by Computer Vision," dalam International Conference on Artificial Intelligence, Las Vegas, 2015.

[9] I.-H. Li, M.-C. Chen, W.-Y. Wang, S.-F. Su dan T.-W. Lai, “Mobile Robot SelfLocalization System Using Single Webcam Distance Measurement Technology in Indoor Environments," Sensors, vol. 14, pp. 2089-2109, 2014.

[10] C. M. Pop, G. L. Mogan dan M. Neagu, "Localization and Path Planning for an Autonomous Mobile Robot Equipped with Sonar Sensor," Applied Mechanics and 
Materials, vol. 772, pp. 494-499, 2015.

[11] D. Vivet, P. Checchin dan R. Chapuis, "Localization and Mapping Using Only a Rotating FMCW Radar Sensor," Sensors, vol. 13, no. 4, p. 4527-4552, 2013.

[12] E. Rakhman, D. Saefudin dan N. C. Basjaruddin, "Intelligent Driver Information System Berbasis GPS," dalam Industrial Research Workshop and National Seminar, Bandung, 2013.

[13] N. C. Basjaruddin, Kuspriyanto, D. Saefudin, E. Rakhman dan A. M. Ramadlan, "Overtaking Assistant System based on Fuzzy Logic," Telkomnika (Telecommunication Computing Electronics and Control), vol. 13, no. 1, 2015.

[14] N. C. Basjaruddin, Kuspriyanto, D. Saefudin dan G. Putra, "Sistem Penghindar Tabrakan Frontal Berbasis Logika Fuzzy," Jurnal Nasional Teknik Elektro dan Teknologi Informasi (JNTETI), vol. 5, no. 3, pp. 228-232, 2016. 